(RESEARCH ARTICLE)

\title{
Investigation of the toxic effects of herbicides on some selected microbial populations from soil
}

\author{
Nkamigbo Promise Ngozi, Mbachu Ifeoma Adaora Chima and Uba Bright Obidinma * \\ Department of Microbiology, Chukwuemeka Odumegwu Ojukwu University, P.M.B.02 Uli, Anambra State, Nigeria.
}

Publication history: Received on 23 March 2020; revised on 04 April 2020; accepted on 06 April 2020

Article DOI: https://doi.org/10.30574/wjarr.2020.6.1.0077

\begin{abstract}
The toxic effect of herbicide on some selected microbial populations from soil was investigated. Soil samples were collected from two unpolluted designated fields of Chukwuemeka Odumegwu Ojukwu University and later polluted with herbicides at different application rates $(0.1 \%, 0.2 \%, 0.5 \%, 1 \%$ and $5 \%)$ and periods using spraying method. Standard chemical processes were used for determining physico-chemical parameters of the soil while isolation, enumerating the population of the microorganisms and identification of the isolates were determined using standard microbiological methods. The result revealed that the soil samples are slightly acidic, sandy clay loam type, lower organic carbon content, higher total nitrogen and phosphorus contents and moderate water holding capacity. The isolates Pseudomonas aeruginosa, Bacillus vallismottis, Aeromonas hydrophila and Enterobacter clocea were selected using selective media and identified. Pseudomonas aeruginosa and Bacillus vallismottis had the least (zero CFU/g) and maximum population counts $\left(10 \times 10^{7} \mathrm{CFU} / \mathrm{g}\right)$ during glyphosate exposure while Pseudomonas aeruginosa and Enterobacter clocea had the least (zero CFU/g) and maximum population counts $\left(2.50 \times 10^{7} \mathrm{CFU} / \mathrm{g}\right)$ during 2,4 - D amine exposure for 15 days, respectively. Thus, the application of glyphosate and 2, 4 - D amine herbicides on the soil have resulted into lower counts of the selected microbial groups. The inhibitions of their growths are dependent on concentration and exposure period, although 2, 4 - D amine had more inhibition than the glyphosate herbicide.
\end{abstract}

Keywords: Herbicide; Microbial Population; Toxicity; Soil

\section{Introduction}

Nigeria is a densely populated country. About $80 \%$ of people obtain their livelihood through agriculture or agriculturalbased industries. To meet the demand of this ever-growing population, the agricultural production needs to be increased, to which the use of herbicides with an objective to effectively eradicate crop destroyers, becomes imperative [1]. Herbicides are defined as any substance, individually or in mixtures, whose function is to control, destroy, repel or mitigate the growth of weed in a crop [2]. Herbicides in their natural state may be solid, liquid, volatile, non-volatile, soluble or insoluble; hence these have to be made in form suitable and safe for their field use. An herbicide formulation is prepared by the manufacturer by blending the active ingredient with substances like solvent, surfactants, sticker and stabilizer to allow mixing, dilution, application and stability [3].

In Nigeria, herbicides have since effectively been used to control weeds in agricultural systems. As farmers continue to realize the usefulness of herbicides, larger quantities are applied to the soil. But the fate of these compounds in the soils is becoming increasingly important since they could be leached, in which case groundwater is contaminated or immobile, and persist on the top soil. These herbicides could then accumulate to toxic levels in the soil and become harmful to microorganisms, plant, wild life and man. There is an increasing concern that herbicides not only affect the target organisms (weeds) but also the microbial communities present in soils, and these non-target effects may reduce the performance of important soil functions. These critical soil functions include organic matter degradation, the nitrogen cycle and methane oxidation $[4,5,6]$.

\footnotetext{
* Corresponding author: Uba Bright Obidinma Email address: ubabright4real@yahoo.com
} 
Numerous studies have shown the effect of herbicides on soil micro-organism populations that ultimately affect the rates of decomposing labile, celluloses and recalcitrant like lignin, respectively, in a variety of ecosystems [1, 6, 7, 8]. Although, their accurate numbers are still not very clear mainly because of rapid changes in the populations [9, 10] but a healthy population of microorganisms can stabilize the ecological system in soil [9]. Thus, the changes in the population of these micro-organisms will affect the ability of the soil to regenerate nutrients to support plant growth [7]. Literatures abound on the inhibition of the test herbicides N-phosphonomethyl glycine (Glyphosate) and 2,4dichlorophenoxyacetic acid (2, 4-D amine) on microbial populations but there is paucity of information on their toxicities to selected microbial populations such as Pseudomonas aeruginosa, Bacillus vallismottis, Aeromonas hydrophila and Enterobacter clocea as these organisms are known as biofertilizers which have wide applications in agriculture system of Nigeria. This study was designed to investigate the effect of two types of herbicides on microbial populations isolated from soil.

\section{Material and methods}

\subsection{Study area}

Chukwuemeka Odumegwu Ojukwu University, Uli Campus was the sampling location for this study. Uli is a town in Anambra State of the South east region of Nigeria, with a population density of about 250,000 . The city is located East of the River Niger, and about $26 \mathrm{Km}$ South East of Onitsha in Anambra State. It falls within the tropical rain forest region of Nigeria.

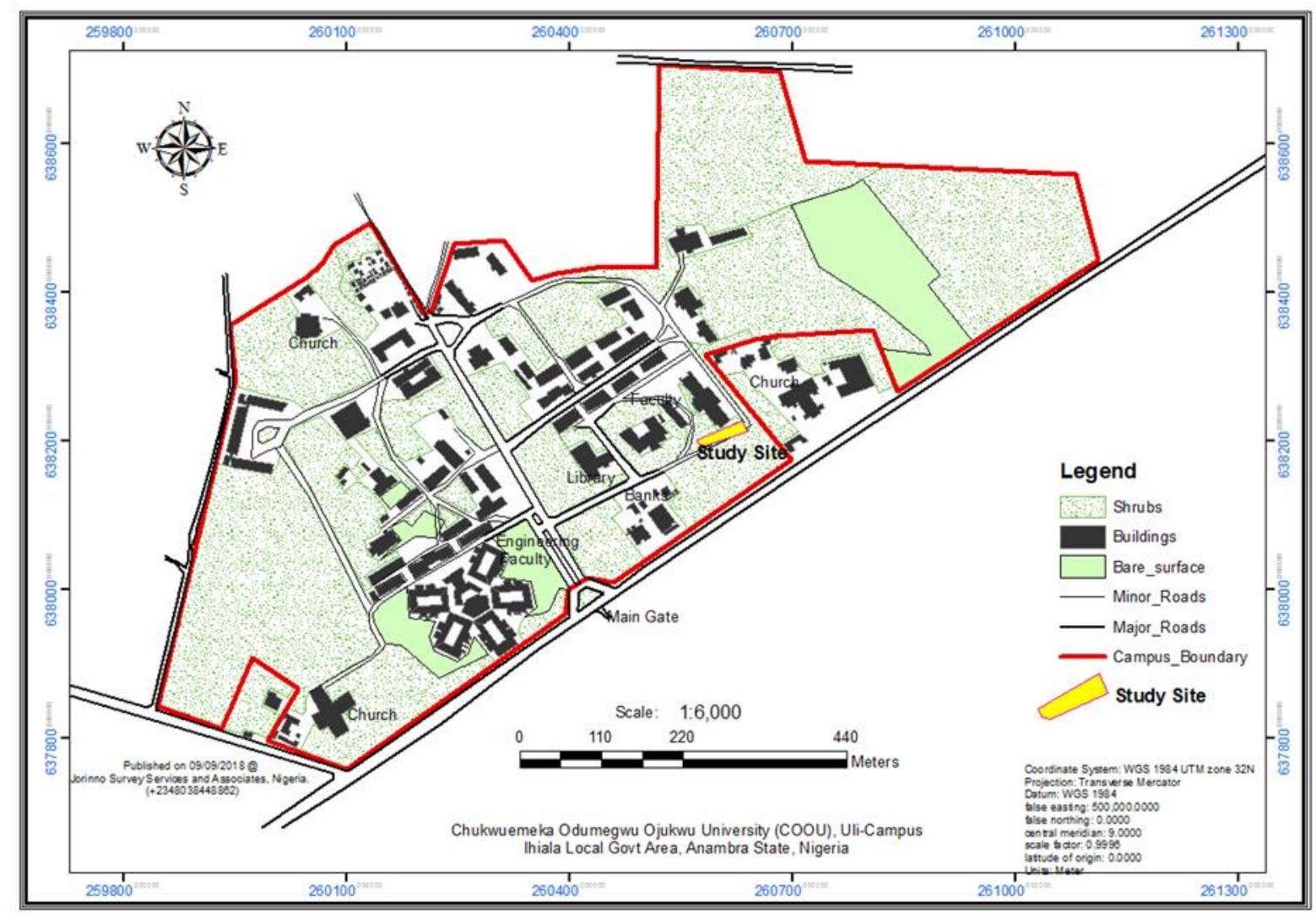

Figure 1 Location of Study Site in the Map of COOU, Uli Campus, in Ihiala Local Govt Area, Anambra State.

\subsection{Herbicide selection}

The herbicides used in this study were obtained from an agricultural market in Onitsha, Anambra State. The herbicides are N-phosphonomethyl glycine (Glyphosate) and 2,4- dichlorophenoxyacetic acid (2, 4-D amine). These herbicides are among the common herbicides used by the local farmers in the study area for their agricultural practices. 


\subsection{Soil treatment}

The soil treatment was carried out using the modified method of Sebiomo et al. [6]. Six (6) points on the two fields were mapped out for five different treatments and controls for the two herbicides previously described. The percentage of herbicide treatment given to these points are: $0.1,0.2,0.5,1$ and $5 \%$, respectively. These treatments lasted for a period of 15 days. The herbicides were applied by the spraying technique with the aid of a local sprayer.

\subsection{Soil sample collection}

By adopting the modified method of Sebiomo et al. [6], the soil samples were collected before and after herbicide treatments from different points within two fields in Chukwuemeka Odumegwu Ojukwu University between 11 am to $12 \mathrm{am}$ each collection day at a depth of $5 \mathrm{~cm}$. All samples were collected using sterile soil auger. Samples were kept in sterilized $100 \mathrm{ml}$ beakers, and labeled accordingly. The samples were transported to the Microbiology Laboratory of Chukwuemeka Odumegwu Ojukwu University and were immediately analyzed for their physicochemical and microbiological properties.

\subsection{Physicochemical analysis of the soil sample}

The following parameters such as $\mathrm{pH}$, soil particle analysis, total organic carbon (TOC), nitrogen, phosphorus and water holding capacity were analyzed for the natural untreated soil by adopting the standard methods of APHA [11] and AOAC [12].

\subsection{Baseline determination of treated soil}

The baseline analysis of the selected microbial populations was carried out on the non -herbicide treated soil [13, 14].

\subsection{Microbial analysis}

\subsubsection{Serial dilution and isolation}

The selected bacteria groups were isolated and enumerated from the treated soil samples using Nutrient agar, Cetrimide agar, Ryan agar, and Eosin Methylene Blue agar. A tenfold serial dilution of the sample was carried out by adding $1 \mathrm{~g}$ of soil sample aseptically into test tubes containing $9 \mathrm{ml}$ of distilled water labeled $10^{-1}$ to $10^{-10}$. Dilution factor of $10^{7}$ was used with the aid of a sterile pipette in a repeated manner. With another sterile pipette, $0.1 \mathrm{ml}$ aliquots of the appropriate dilution were spread plated on the surfaces of the sterile solidified media in duplicate with the aid of a glass spreader. Precisely, $10^{-7}$ dilutions were spread plated. The spreader was disinfected after each successive spreading by dipping it in $70 \%$ ethanol and then passing it through flame of a Bunsen burner. The inoculated plates were sealed with adhesive tape to prevent contamination and then incubated at room temperature for 18 - $24 \mathrm{~h}$. After incubation, colonies were counted using a colony counter $[13,14]$.

\subsubsection{Bacterial characterization and identification}

The bacterial isolates were characterized based on cultural characteristics, staining reactions and biochemical reactions. Identification was thereafter carried out through DNA isolation, polymerase chain reaction, gel electrophoresis, sequencing and blasting $[13,15]$.

\subsection{Statistical management}

The results were considered statistically significant if the threshold value $\mathrm{P}<0.05$. Ordinary two factors analysis of variance (ANOVA) was adopted for analysis of mean between groups of treatment followed by post Turkey's multiple comparism test using GraphPad Prism Statistical software version 7.00 (Graphpad Software Inc. San Diego CA).

\section{Results and discussion}

The result of the physicochemical profile of the untreated soil sample to ascertain soil type, total organic carbon, percentage nitrogen, phosphorus and water holding capacity is presented in Table 1 . From the result, field A had the highest $\mathrm{pH}$, moisture content, percentage sand and silt of 5.00, $14.00 \%, 65.56 \%, 22.76 \%$ and sandy loam sediment type while field B had the highest percentage clay, total organic carbon, total nitrogen, phosphorus, water holding capacity of $25.64 \%, 0.16 \%, 4.62 \%, 12.0 \mathrm{mg} / \mathrm{kg}, 55.32 \%$ and sandy clay loam as sediment type. The result in Table 1 revealed the soil samples are slightly acidic, low moisture content, sandy clay loam type, lower organic carbon, higher total nitrogen and phosphorus contents and moderate water holding capacity. 
Table 1 Physicochemical profile of untreated soil samples

\begin{tabular}{lll}
\hline Parameter & Field A & Field B \\
\hline $\mathrm{pH}$ & 5.00 & 4.50 \\
Soil particle size (\%) & & \\
Sand & 65.56 & 50.09 \\
Silt & 22.76 & 16.26 \\
Clay & 11.68 & 25.64 \\
Soil type & Sandy loam & Sandy clay loam \\
Moisture content (\%) & 14.00 & 10.00 \\
TOC content $(\%)$ & 0.13 & 0.16 \\
Nitrogen content $(\%)$ & 3.36 & 4.62 \\
Phosphorus content $(\mathrm{mg} / \mathrm{kg})$ & 7.18 & 12.1 \\
W H C $\%$ ) & 44.92 & 55.32 \\
\hline
\end{tabular}

Key: Field A = Glyphosate untreated soil; Field B = 2,4-D amine untreated soil; TOC = Total organic carbon; WHC = Water holding capacity

In the present study, four (4) different species of bacteria that are soil friendly and improve soil health were isolated from the soil and the result of the baseline features of population of the selected microbial groups of the non - herbicide treated soil is presented in Table 2. From the results, field A had the highest count of Bacillus vallismottis and Enterobacter clocea with $13.00 \times 10^{7} \mathrm{CFU} / \mathrm{g}$ and $3.0 \times 10^{7} \mathrm{CFU} / \mathrm{g}$ while field B had the highest counts of Pseudomonas aeruginosa and Aeromonas hydrophila with $1.8 \times 10^{7} \mathrm{CFU} / \mathrm{g}$ and $8.00 \times 10^{7} \mathrm{CFU} / \mathrm{g}$, respectively. The result in Table 2 revealed that the soil samples are reservoirs of the selected microbial groups as these organisms have been recognized as agriculturally important microbes and have been implicated for their plant growth stimulating capabilities. Previous studies by Devi and Sumathy [16] and Ogbo and Odo [17] reported that these microbes as important biofertilizers for crop cultivation, safeguarding the soil health and improving the quality of crop products.

Table 2 Baseline features of population of the selected microbial groups of the non - herbicide treated soil

\begin{tabular}{lll}
\hline Organisms & Field A & Field B \\
\hline Bacillus vallismottis & 13.00 & 12.50 \\
Pseudomonas aeruginosa & 1.40 & 1.80 \\
Enterobacter clocea & 1.10 & 8.00 \\
Aeromonas hydrophila & 3.20 & 1.80 \\
\hline
\end{tabular}

Key: Field A = Glyphosate untreated soil; Field B = 2,4-D amine untreated soil.

The results of the growth response of Bacillus vallismottis, Pseudomonas aeruginosa, Aeromonas hydrophila and Enterobacter clocea to glyphosate and 2,4 - D amine exposure after 15 days of treatment ((CFU/g x107) are presented in Tables 3 - 10. From the result, Pseudomonas aeruginosa and Bacillus vallismottis had the least (zero CFU/g) and maximum population counts $\left(10 \times 10^{7} \mathrm{CFU} / \mathrm{g}\right)$ during glyphosate exposure while Pseudomonas aeruginosa and Enterobacter clocea had the least (zero CFU/g) and maximum population counts $\left(2.50 \times 10^{7} \mathrm{CFU} / \mathrm{g}\right)$ during 2,4 - D amine exposure for 15 days. Moreso, Bacillus vallismortis had more growth in all the five concentrations while Pseudomonas aeruginosa had no growth in all the concentrations on day 15 on both glyphosate and 2,4-D herbicides. The results in Tables 3 - 10 generally revealed that there was remarkable decrease in population counts as the days of treatment advanced. The population counts could be said to be concentration dependent. Comparatively, 2,4 - D amine herbicide seems to have greater inhibition effect than glyphosate. The reasons for these decreases could be due to toxicity effects and the adsorption of the herbicides in soil or because the soil microorganisms were not fully adapted to the herbicide itself. Statistically, significant differences $(\mathrm{P}<0.05)$ exist between the concentrations and days of treatment for each selected microbial group further proving that concentration and exposure period inhibited the growth of the selected microbial groups. The results corroborate with the publication of Zain et al. [7] who reported that the growth inhibition of bacteria showed an increasing trend with increased herbicide concentrations, and the microbial population showed different degree of sensitivity to the herbicide compounds at different sampling dates (exposure periods). Sebiomo et 
al. [6] reported that herbicide treatment had high significant effect on bacterial count $(\mathrm{P}<0.001)$. The interaction between the herbicides and the weeks of herbicide treatment also resulted to high significant effect on bacterial count $(\mathrm{P}<0.001)$. The weeks of herbicide treatment followed similar trend as stated above $(\mathrm{P}<0.001)$. Ayansina and 0so [18] discovered that higher concentrations of herbicides treatments resulted in much lower microbial counts when compared to soils treated with recommended doses. The observations of these authors validate the findings in this study.

Table 3 Growth response of Bacillus vallismottis to glyphosate exposure after 15 days of treatment ((CFU/ g x107)

\begin{tabular}{|c|c|c|c|c|c|c|}
\hline \multirow[t]{2}{*}{ Day } & \multicolumn{4}{|c|}{ Herbicide concentration (\%) } & \multirow[b]{2}{*}{5.0} & \multirow[b]{2}{*}{ Control } \\
\hline & 0.1 & 0.2 & 0.5 & 1.0 & & \\
\hline 1 & 17.50 & 13.10 & 11.00 & 7.50 & 3.30 & 20.04 \\
\hline 3 & 14.80 & 10.00 & 9.00 & 5.30 & 4.00 & 20.10 \\
\hline 6 & 11.20 & 8.60 & 7.80 & 4.80 & 3.40 & 21.20 \\
\hline 9 & 8.10 & 5.70 & 9.20 & 5.00 & 5.20 & 19.40 \\
\hline 12 & 11.90 & 10.50 & 10.00 & 9.00 & 8.40 & 18.90 \\
\hline 15 & 4.80 & 10.00 & 4.30 & 3.50 & 3.00 & 19.80 \\
\hline
\end{tabular}

Table 4 Growth response of Pseudomonas aeruginosa to glyphosate exposure after 15 days of treatment ((CFU/g x107)

\begin{tabular}{|c|c|c|c|c|c|c|c|}
\hline \multirow[t]{2}{*}{ Day } & \multicolumn{6}{|c|}{ Herbicide concentration (\%) } & \multirow[b]{2}{*}{ Control } \\
\hline & 0.1 & 0.2 & 0.5 & 1.0 & 5.0 & & \\
\hline 1 & 1.40 & 1.00 & & 0.60 & 0.50 & 0.50 & 12.30 \\
\hline 3 & 1.40 & 1.00 & & 0.80 & 3.30 & 4.00 & 12.30 \\
\hline 6 & 4.30 & 6.00 & & 3.50 & 3.20 & 0.60 & 11.90 \\
\hline 9 & 1.30 & 0.90 & & 0.90 & 0.70 & 0.50 & 12.40 \\
\hline 12 & 1.10 & 0.70 & & 0.40 & 0.30 & - & 12.35 \\
\hline 15 & - & - & & - & - & - & 12.30 \\
\hline
\end{tabular}

Key: Day 1 analysis is immediately after herbicide application; - indicates no growth

Table 5 Growth response of Enterobacter clocea to glyphosate exposure after 15 days of treatment ((CFU/g x107)

\begin{tabular}{|c|c|c|c|c|c|c|}
\hline \multirow[t]{2}{*}{ Day } & \multicolumn{3}{|c|}{ Herbicide concentration (\%) } & \multirow[b]{2}{*}{1.0} & \multirow[b]{2}{*}{5.0} & \multirow[b]{2}{*}{ Control } \\
\hline & 0.1 & 0.2 & 0.5 & & & \\
\hline 1 & 9.80 & 8.50 & 8.20 & 8.00 & 6.10 & 14.60 \\
\hline 3 & 8.00 & 7.10 & 7.00 & 6.40 & 5.90 & 16.80 \\
\hline 6 & 4.10 & 2.70 & 2.20 & 1.10 & 0.20 & 15.30 \\
\hline 9 & 4.90 & 4.50 & 2.00 & 1.70 & 0.40 & 14.90 \\
\hline 12 & 3.70 & 2.60 & 2.00 & 1.60 & 1.10 & 15.00 \\
\hline 15 & 2.00 & 1.40 & 0.90 & 0.50 & 0.20 & 16.10 \\
\hline
\end{tabular}


Table 6 Growth response of Aeromonas hydrophila to glyphosate exposure after 15 days of treatment ((CFU/g x107)

\begin{tabular}{lllllll}
\hline Day & \multicolumn{7}{l}{ Herbicide concentration (\%) } \\
\hline & $\mathbf{0 . 1}$ & $\mathbf{0 . 2}$ & $\mathbf{0 . 5}$ & $\mathbf{1 . 0}$ & $\mathbf{5 . 0}$ & Control \\
\hline 1 & 4.00 & 2.30 & 2.10 & 1.50 & 0.30 & 12.70 \\
3 & 3.00 & 1.80 & 0.80 & 0.60 & 0.40 & 14.10 \\
6 & 3.20 & 1.60 & 1.80 & 0.80 & 1.40 & 13.90 \\
9 & 2.10 & 1.70 & 1.20 & 0.90 & 0.20 & 13.10 \\
12 & 1.90 & 10.50 & 10.00 & 9.00 & 8.40 & 14.00 \\
15 & 1.70 & 0.90 & 0.60 & 0.50 & 0.20 & 13.40 \\
\hline \multicolumn{7}{r}{} \\
\hline
\end{tabular}

Table 7 Growth response of Bacillus vallismottis to 2, 4- D amine exposure after 15 days of treatment ((CFU/g x107)

\begin{tabular}{lllllll}
\hline Day & \multicolumn{7}{l}{ Herbicide concentration (\%) } \\
\hline & $\mathbf{0 . 1}$ & $\mathbf{0 . 2}$ & $\mathbf{0 . 5}$ & $\mathbf{1 . 0}$ & $\mathbf{5 . 0}$ & Control \\
\hline 1 & 21.20 & 12.00 & 10.10 & 7.90 & 6.00 & 20.04 \\
3 & 14.80 & 11.40 & 10.10 & 8.30 & 7.20 & 20.10 \\
6 & 6.90 & 5.60 & 5.40 & 4.20 & 3.30 & 21.20 \\
9 & 5.10 & 4.70 & 3.20 & 1.90 & 0.20 & 19.40 \\
12 & 4.30 & 4.00 & 3.30 & 3.50 & 3.00 & 18.90 \\
15 & 1.70 & 1.90 & 1.60 & 0.60 & 0.20 & 19.80 \\
\hline
\end{tabular}

Key: Day 1 analysis is immediately after herbicide application

Table 8 Growth response of Pseudomonas aeruginosa to 2, 4 - D amine exposure after 15 days of treatment ((CFU/g $\left.\mathrm{x} 10^{7}\right)$

\begin{tabular}{lllllll}
\hline Day & \multicolumn{7}{l}{ Herbicide concentration (\%) } \\
\hline \multicolumn{1}{l}{$\mathbf{0 . 1}$} & $\mathbf{0 . 2}$ & $\mathbf{0 . 5}$ & $\mathbf{1 . 0}$ & $\mathbf{5 . 0}$ & Control \\
\hline 1 & 10.10 & 8.00 & 7.10 & 5.00 & 4.00 & 12.10 \\
3 & 9.80 & 7.40 & 6.10 & 3.30 & 1.20 & 12.30 \\
6 & 1.90 & 1.50 & 1.10 & 1.10 & 0.70 & 11.90 \\
9 & 1.80 & 0.80 & 0.70 & 0.50 & 0.50 & 12.40 \\
12 & 0.80 & 0.40 & 0.40 & 0.40 & - & 12.35 \\
15 & - & - & - & - & - & 12.30 \\
\hline
\end{tabular}


Table 9 Growth response of Enterobacter clocea to 2, 4 - D amine exposure after 15 days of treatment ((CFU/g x107)

\begin{tabular}{lllllll}
\hline Day & \multicolumn{7}{l}{ Herbicide concentration (\%) } \\
\hline & $\mathbf{0 . 1}$ & $\mathbf{0 . 2}$ & $\mathbf{0 . 5}$ & $\mathbf{1 . 0}$ & $\mathbf{5 . 0}$ & Control \\
\hline 1 & 10.80 & 9.70 & 7.30 & 5.50 & 3.00 & 14.60 \\
3 & 8.80 & 7.40 & 5.10 & 3.30 & 2.20 & 16.80 \\
6 & 8.20 & 6.70 & 3.80 & 3.00 & 2.40 & 15.30 \\
9 & 3.90 & 3.20 & 2.10 & 1.50 & 0.50 & 14.90 \\
12 & 3.10 & 1.60 & 1.20 & 0.80 & 0.20 & 15.00 \\
15 & 2.50 & 1.50 & 1.00 & 0.40 & 0.20 & 16.10 \\
\hline \multicolumn{7}{r}{}
\end{tabular}

Table 10 Growth response of Aeromonas hydrophila to 2, 4 - D amine exposure after 15 days of treatment ((CFU/g $\mathrm{x} 10^{7}$ )

\begin{tabular}{lllllll}
\hline Day & \multicolumn{7}{l}{ Herbicide concentration (\%) } \\
\hline & $\mathbf{0 . 1}$ & $\mathbf{0 . 2}$ & $\mathbf{0 . 5}$ & $\mathbf{1 . 0}$ & $\mathbf{5 . 0}$ & Control \\
\hline 1 & 2.80 & 1.70 & 1.50 & 8.50 & 0.50 & 12.70 \\
3 & 1.50 & 1.20 & 0.80 & 0.30 & 0.30 & 14.10 \\
6 & 0.90 & 0.70 & 0.70 & 0.70 & 0.40 & 13.90 \\
9 & 1.70 & 1.20 & 1.10 & 1.50 & 0.50 & 13.10 \\
12 & 2.10 & 1.80 & 1.70 & 1.50 & 0.90 & 14.00 \\
15 & 1.90 & 1.80 & 1.60 & 1.20 & 0.50 & 13.40 \\
\hline \multicolumn{7}{c}{ Key: Day 1 analysis is immediately after herbicide application }
\end{tabular}

The results of the colonial morphology, biochemical and molecular features of the selected bacterial isolates are presented in Table 11 -13. From the results, the colour, margin, elevation, optic and surface colonial characteristics of the bacterial isolates are regular, creamy/greenish/purple pink, convex/entire, raised/flat, opaque/translucent and smooth/wavy. Most isolates were catalase, oxidase, indole, citrate, motility, hydrogen sulphide, methyl red, Voges Proskauer, glucose, sorbitol and fructose positive but negative to inositol sugar. The predominant cell morphology and arrangement are Gram-negative rod-shaped bacteria. All the isolates except D had $100 \%$ similarity to their closest relative in the GenBank. In general, Bacillus vallismottis is Gram positive, rod-shaped and forms creamy round, raised and transparent colonies. It is also positive to spore staining, citrate, motility, glucose, sucrose, maltose, mannitol, lactose, but negative to oxidase, indole and $\mathrm{H}_{2} \mathrm{~S}$. Pseudomonas aeruginosa is Gram negative, irregular, rod-shaped and forms green, opaque and smooth colonies. It is also catalase, oxidase, indole, citrate, motility and $\mathrm{H}_{2} \mathrm{~S}$ positive, but negative to spore staining, glucose, sucrose, lactose and maltose. Aeromonas hydrophila is Gram negative, rod- shaped, and forms greenish dark, round, raised, opaque, smooth colonies with dark centers. It is also positive to lactose, oxidase, catalase, indole, mannitol, maltose, sucrose, but negative to spore staining. Enterobacter clocea is Gram negative rodshaped, and forms purple pink, raised, translucent, smooth colonies. It is positive to catalase, citrate, motility, maltose, mannitol, glucose, sucrose, lactose, but negative to spore staining, oxidase, indole and $\mathrm{H}_{2} \mathrm{~S}$. Devi and Sumathy [16] reported that Gram-negative rod-shaped are the dominant bacterial group used as biofertilizers, while the study by Wesley et al. [1] reported that most of the isolates that were sensitive the agrochemicals toxicity were Bacillus spp., Micrococcus spp., Staphylococcus spp. and Corynebacterium spp. 
Table 11 Colonial morphological features of the selected bacterial isolates

\begin{tabular}{lllllll}
\hline Isolate & Colour & Shape & Margin & Elevation & Optic & Surface \\
\hline A & creamy & round & convex & raised & transparent & wavy \\
B & green & irregular & entire & flat & opaque & smooth \\
C & dark green & round & entire & flat & opaque & smooth \\
D & purple pink & round & entire & raised & translucent & smooth \\
\hline
\end{tabular}

Key: A = Bacillus vallismottis; $\mathrm{B}=$ Pseudomonas aeruginosa; $\mathrm{C}=$ Aeromonas hydrophila and $\mathrm{D}=$ Enterobacter clocea.

Table 12 Biochemical features of the selected bacterial isolates

\begin{tabular}{lllll}
\hline Parameter & A & B & C & D \\
\hline Catalase & + & + & + & + \\
Oxidase & + & + & - & + \\
Indole & + & + & + & + \\
Citrate & + & + & + & + \\
Motility & + & + & + & + \\
$\mathrm{H}_{2} \mathrm{~S}$ & + & + & + & + \\
MR test & + & + & + & + \\
VP test & + & + & + & + \\
Glucose & + & + & + & + \\
Xylose & - & + & + & + \\
Sorbitol & + & + & + & + \\
Fructose & + & + & + & + \\
Inositol & - & - & - & -
\end{tabular}

Key: A = Bacillus vallismottis; $\mathrm{B}=$ Pseudomonas aeruginosa; $\mathrm{C}=$ Aeromonas hydrophila and $\mathrm{D}=$ Enterobacter clocea $;+=$ Positive; $-=$ Negative; $\mathrm{MR}=$ Methyl red; VP = Voges Proskauer; $\mathrm{H}_{2} \mathrm{~S}=$ Hydrogen sulphide production.

Table 13 Molecular features of the selected bacterial isolates

\begin{tabular}{llllllll}
\hline Isolate & $\begin{array}{l}\text { Maximum } \\
\text { score }\end{array}$ & $\begin{array}{l}\text { Total } \\
\text { score }\end{array}$ & $\begin{array}{l}\text { Query } \\
\text { cover }\end{array}$ & E value & Accession & Description & Strain \\
\hline A & 1475 & 1475 & $100 \%$ & 0.0 & AB681417 & B. vallismottis & Strain NBRC 101236 \\
B & 2206 & 2206 & $100 \%$ & 0.0 & LT883143 & P. aeruginosa & Strain NN2 \\
C & 3232 & 4895 & $100 \%$ & 0.0 & KT315926 & A.hydrophila & Strain AH227 \\
D & 3650 & 4824 & $99 \%$ & 0.0 & LOMM00000000 & E. clocea & Strain SENG-6 \\
\hline
\end{tabular}

\section{Conclusion}

This study has revealed that the natural untreated soil samples contain abundant populations of Bacillus vallismottis, Pseudomonas aeruginosa, Aeromonas hydrophila and Enterobacter clocea. The application of glyphosate and 2, 4 - D amine herbicides on the soil have resulted into lower counts of the selected microbial groups. The inhibitions of their growths are dependent on concentration and exposure period, although 2, 4 - D amine had more inhibition than the glyphosate herbicide. 


\section{Compliance with ethical standards}

\section{Acknowledgments}

Special thanks go to Mr Ike Victor Echezona of Microbiology Department, Chukwuemeka Odumegwu Ojukwu University, P.M.B.02 Uli, Anambra State, Nigeria for his technical assistance.

\section{Disclosure of conflict of interest}

Nkamigbo, P. N. was involved in the collection of samples, experimental design, laboratory work and research typing, Mbachu, I.A.C. supervised and proof- read the write while Uba, B.O. was involved partly in the laboratory work, statistical analysis and manuscript write up. Disclosure of conflict of interest none to declare.

\section{References}

[1] Wesley B, Ajugwo GC, Adeleye SA, Ibegbulem CR and Azuike PA. (2017) Effects of agrochemicals (insecticides) on microbial population in soil. EC Microbiology, 8 (4), 211 -221.

[2] Rose MT, Cavagnaro TR, Scanlan CA, Rose JV, Kimber SK, Kookona RS and Van ZL. (2016). Impact of herbicides on soil biology and function. Advances in Agronomy, 36, 133 - 220.

[3] Tominack RL. (2000). Herbicide formulations. Journal of Toxicology, 38(2), 129 - 135.

[4] Hutsch BW. (2001). Methane oxidation in non-flooded soils as affected by crop production: Invited paper. European Journal of Agronomy, 14, 237 - 260.

[5] Ayansina ADV, Ogunshe AAO and Fagade OE. (2003). Environment impact assessment and microbiologist: An overview. Proceeding of 11th Annual National Conference of Environment and Behaviour Association of Nigeria (EBAN), $26-27$.

[6] Sebiomo A, Ogundero VW and Bankole SA. (2011). Effect of four herbicides on microbial population, soil organic matter and dehydrogenase activity. Journal of Biotechnology, 10 (5), 770 - 778.

[7] Zain NMM, Mohamad, RB, Sijam K, Morshed MM and Awang Y. (2013). Effects of selected herbicides on soil microbial populations in oil palm plantation of Malaysia: A microcosm experiment. African Journal of Microbiology Research, 7(5), $367-374$.

[8] Tejashree M, Reddy RS and Anuradha G. (2018). Effect of herbicides on microbial population and soil enzymes in Bt cotton cultivated soils. International Journal of Current Microbiology and Applied Sciences, 7(9), 3240 - 3255.

[9] Chauhan AK, Das A, Kharkwal H, Kharkwal AC and Varma A. (2006). Impact of microorganisms on environment and health. In Chauhan AK and Varma A (Eds.). Microbes: Health and Environment, Anshan, UK, 1 - 12.

[10] Das A, Prasad R, Bhatnagar K, Lavekar GS and Varma A. (2006). Synergism between medicinal plants and microbes. In Chauhan AK and Varma A (Eds.). Microbes: Health and Environment, Anshan, UK, 13 - 64.

[11] AOAC (2012). Official method of analysis, Nineteenth edition. Association of Official Analytical Chemists, Washington DC, USA, 121 - 130.

[12] APHA (2012). Standard methods for examination of water and wastewater, twenty second edition. American Public Health Association, Washington, DC, USA, 1360.

[13] Cheesbrough M. (2006). District laboratory practice in tropical countries, Second edition. Cambridge University Press, New York USA, 38 - 70.

[14] Chikere CB, Okpokwasili GC and Ichiakor 0. (2009). Characterization of hydrocarbon utilizing bacteria in tropical marine sediments. African Journal of Biotechnology, 8 (11), 2541 - 2544.

[15] Ubani O, Atagana HI, Thantsha MS and Rasheed A. (2016). Identification and characterization of oil sludge degrading bacteria isolated from compost. Archives of Environmental Protection, 42 (2), 67 - 77.

[16] Devi V and Sumathy VJH. (2018). Production of biofertilizers from agro - wastes. International Journal of Engineering and Techniques, 4 (1), 453 - 466.

[17] Ogbo FC and Odo MO. (2011). Potential of risk husk and cassava peel as carriers for biofertilizer production. Nigeria Journal of Biotechnology, 23, $1-4$. 
[18] Ayansina ADV and Oso BA. (2006). Effect of two commonly used herbicides on soil micro flora at two different concentrations. African Journal of Biotechnology, 5(2), 129 - 132.

\section{How to cite this article}

Nkamigbo PN, Mbachu IAC and Uba BO. (2020). Investigation of the toxic effects of herbicides on some selected microbial populations from soil. World Journal of Advanced Research and Reviews, 6(1), 40-49. 